Data Descriptor

\title{
Plant Trait Dataset for Tree-Like Growth Forms Species of the Subtropical Atlantic Rain Forest in Brazil
}

\author{
Arthur Vinicius Rodrigues ${ }^{1, *(1)}$, Fábio Leal Viana Bones ${ }^{2}$ (D), Alisson Schneiders ${ }^{2}$, \\ Laio Zimermann Oliveira ${ }^{3}$ (D), Alexander Christian Vibrans ${ }^{3}$ (D) and André Luís de Gasper 1,2 (D) \\ 1 Programa de Pós-Graduação em Engenharia Florestal, Universidade de Blumenau-FURB, Blumenau \\ 89030-000, Santa Catarina, Brazil; algasper@furb.br \\ 2 Departamento de Ciências Naturais, Universidade de Blumenau-FURB, Blumenau 89030-903, \\ Santa Catarina, Brazil; bonesfabio@gmail.com (F.L.V.B.); alissonschneiders@gmail.com (A.S.) \\ 3 Departamento de Engenharia Florestal, Universidade de Blumenau-FURB, Blumenau 89030-000, \\ Santa Catarina, Brazil; laiozoliveira@gmail.com (L.Z.O.); acv@furb.br (A.C.V.) \\ * Correspondence: rodrigues.arthur.v@gmail.com
}

Received: 18 April 2018; Accepted: 6 May 2018; Published: 8 May 2018

\begin{abstract}
Plant functional traits have been incorporated in studies of vegetation ecology to better understand the mechanisms of ecological processes. For this reason, a global effort has been made to collect functional traits data for as many species as possible. In light of this, we identified the most common species of an area of $15,335 \mathrm{~km}^{2}$ inserted in the subtropical Atlantic Rain Forest in Southern Brazil. Then, we compiled functional trait information mostly from field samples, but also from herbarium and literature. The dataset presents traits of leaf, branch, maximum potential height, seed mass, and dispersion syndrome of 117 species, including trees, tree ferns, and palms. We also share images of anatomical features of branches used to measure wood traits. Data tables present mean trait values at individual and species level. Images of wood and stomatal features may be useful to assess other anatomical traits that were not covered in the data tables for the anatomical determination of species and/or for educational purposes.
\end{abstract}

Dataset: doi: 10.5281/zenodo.1241023. link: https:/ / zenodo.org/record/1241023

Dataset License: CC-BY 4.0

Keywords: ecology; functional trait; leaf traits; wood traits; hydraulic conductance; seed mass; stomata traits; wood anatomical images; stomata images

\section{Introduction}

In the last decades, plant ecologists have employed trait-based approaches to investigate relationships among biological groups and the environment [1-4]. In general, trait-based approaches are grounded in community theories, e.g., niche-theory and biogeography of islands. These theories state that differences in plant fitness are associated with their potential to use and allocate resources, thus influencing their competitive capacity, e.g., [5]. Hence, a community would be an assembly of the available species in the regional species pool that are capable of establishing themselves in a given area through dispersal mechanisms, suitability to local environment, and interaction with other species [6]. Furthermore, plant functional traits have been recognized as drivers of ecosystem processes [7,8].

Traits are any morphological, physiological, or phenological feature that is measurable at individual level [9]. In turn, functional traits are the traits that directly affect performance traits 
(vegetative biomass, reproductive output, and plant survival), and, therefore, indirectly affect individual fitness (growth, reproduction, and survival) [9]. It is important to state this distinction because a functional trait, in this sense, depends on the relationship between a trait and performance traits. Thus, a functional trait should be selected according to the ecological hypothesis under investigation [10].

Functional traits related to leaf, wood, seed dispersal, and water transport have been used to support theories of plant ecological strategies [11], response of communities to environmental gradients [12], and effects on ecosystem properties [7,13] and functioning [14,15]. Given the importance of trait-based approaches to model ecosystem processes, a global effort to collect data on functional traits for as many plant species as possible has been made [16]. However, just a few traits were sampled for a considerable amount of species to allow for global studies (only six traits were used in a recent study based on the TRY-database [4]); in addition, there is a lack of functional traits data of species occurring in the Brazilian Atlantic Forest hotspot.

In light of this, we conducted a local abundance-based sample strategy [17] to collect functional trait data of the most common species in the Itajaí-Açu watershed, inserted in the subtropical Atlantic Rain Forest, Southern Brazil. Our aim was to build a useful functional traits dataset that could be extrapolated to communities in the same region to investigate community assembly processes and plant ecological strategies. Moreover, our dataset may be used in broader scales, given that most of the species in our study area have wide geographical distribution, and that global datasets are built from several regional studies.

Here, we present a dataset containing images and data tables that were used to build our main data table that includes the mean values of 17 functional traits of 117 species occurring in the subtropical Atlantic Rain Forest. These traits cover leaf, wood, seed, height, and water-flux related functions. The images in the dataset refer to branches' wood macroanatomy and stomata anatomy.

\section{Data Description}

We present a plant trait dataset with images and data tables of 117 species, including trees, tree ferns, and palms. These species represent most of the common species of the subtropical Atlantic Rain Forest.

\subsection{Images}

The images are compacted in .zip files separated by view type (stomata, wood panoramic view, and wood zoomed view). All images are in .tiff format and have their correspondent metadata file $(. x \mathrm{l})$, which contains the image scale, as well as the measurements that were made in the Zen Blue software (details in methods).

The stomata_image.zip file contains two folders, for abaxial (1947 images; examples in Figure 1) and adaxial leaf images (30 images). This file has three parts for download because of its size. Five images of stomata in different positions of the leaf were taken by individual samples. Stomata images are named by species name, number of individual sample, and the number of the image in parenthesis (e.g., Dicksonia sellowiana 1 (1), Dicksonia sellowiana 1 (2)).

The wood_panonoramic_view.zip and wood_zoom_5x_view.zip contain 509 and 511 images, respectively (examples in Figure 2). In each of them, the image file name is the scientific name of the species followed by the number of its individual sample (e.g., Dicksonia sellowiana 1). 


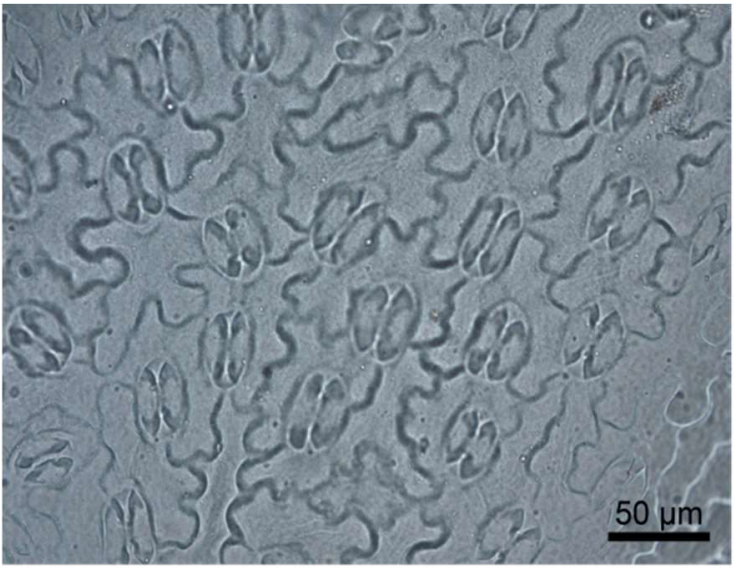

(a)

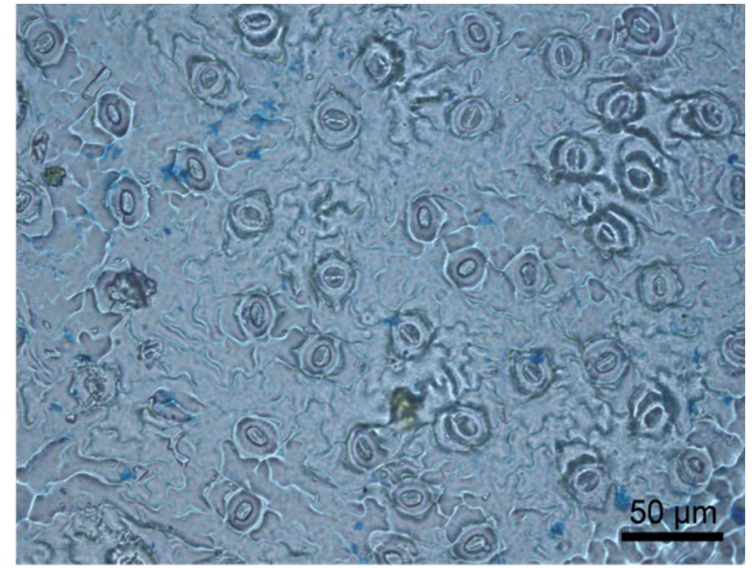

(b)

Figure 1. Examples of stomata images in the dataset; these images are the leaf epidermis impression in a clear nail polish lamina. (a) Stomata of the tree fern Dicksonia sellowiana, and (b) the tree Annona emarginata.

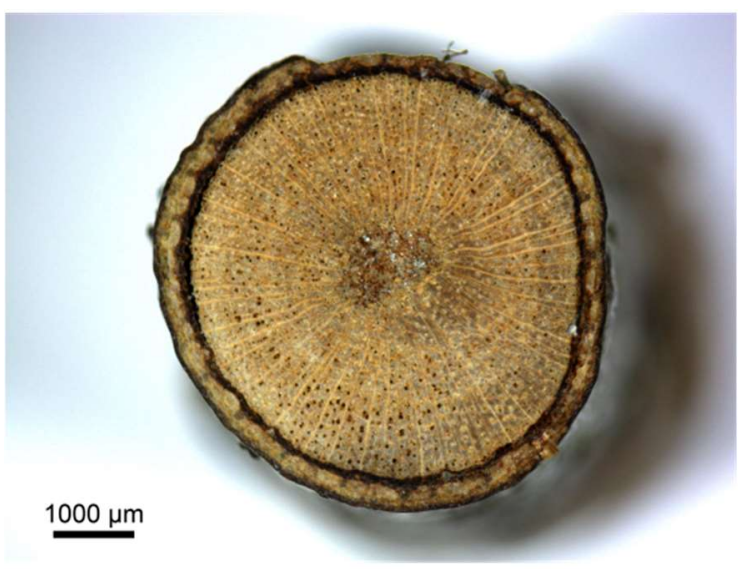

(a)

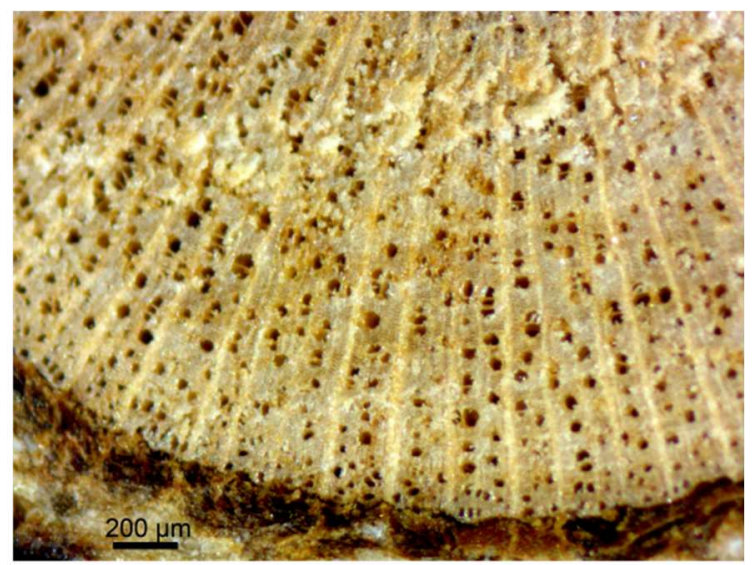

(b)

Figure 2. Examples of wood images in the dataset; (a) wood panoramic view; and (b) zoomed view of Cryptocarya aschersoniana.

\subsection{Data Tables}

The dataset contains three data tables. (1) The individual-level_trait.csv file describes the 559 collected samples that were used to build the dataset. Trait values in this file represent the mean value per sample. Table 1 presents the column description for the individual-level_trait.csv file. (2) The species-level_trait.csv file has the mean of 17 functional traits of 117 species. Table 2 presents the column description for this data table. (3) The seed_mass.xls $x$ file is the detailed description of how we obtained the mean seed dry mass for each species in the dataset. This file has two spreadsheets; the first, namely, Seed mass, contains the values, and the second (References) contains the references cited in the Seed mass spreadsheet. Table 3 shows the description of each column in the seed_mass.xls $x$ file. 
Table 1. Description of columns in the individual-level_trait.csv file.

\begin{tabular}{lll}
\hline \multicolumn{1}{c}{ Column Names } & \multicolumn{1}{c}{ Variable } & \multicolumn{1}{c}{ Unit } \\
\hline Species & Scientific name & - \\
Sample & Number of samples related to an species & $1-6$ \\
Long_W_decimal & Longitude coordinate & decimals \\
Lat_S_decimal & Latitude coordinate & decimals \\
Date_dd/mm/yyyy & Sample collection date & dd/mm/yyyy \\
Chlorophyll_FCI & Chlorophyll content per leaf area & FCI \\
LeafThick_mm & Leaf thickness & $\mathrm{mm}$ \\
LWM_g & Leaf wet mass & $\mathrm{g}$ \\
LeafArea_cm 2 & Leaf area & $\mathrm{cm}{ }^{2}$ \\
LeafTough_N/mm & Leaf toughness & $\mathrm{N} / \mathrm{mm}$ \\
LDM_g & Leaf dry mass & $\mathrm{g}$ \\
BarkProp_\% & Proportion of bark cross-sectional area & $\%$ \\
PithProp_\% & Proportion of pith cross-sectional area & $\%$ \\
XylProp_\% & Proportion of xylem cross-sectional area & $\%$ \\
BranchVol_g/cm ${ }^{3}$ & Branch volume & $\mathrm{cm}$ \\
BDM_g & Branch dry mass & $\mathrm{g}$ \\
VesselDens_n/mm ${ }^{2}$ & Vessel density & $\mathrm{n} / \mathrm{mm}^{2}$ \\
VesselDiam_micom & Mean vessel diameter & $\mu \mathrm{m}$ \\
StomDens_n/mm & Stomata density & $\mathrm{n} / \mathrm{mm}^{2}$ \\
StomLength_micom & Mean stomata length & $\mu \mathrm{m}$ \\
\hline
\end{tabular}

Table 2. Description of columns in the species-level_trait.csv file.

\begin{tabular}{llll}
\hline \multicolumn{1}{c}{ Column Names } & \multicolumn{1}{c}{ Variable } & \multicolumn{1}{c}{ Unit } \\
\hline Species & Scientific name & - & \\
SLA_cm $/$ g & Specific leaf area & $\mathrm{cm}^{2} / \mathrm{g}$ & $\mathrm{mg} / \mathrm{g}$ \\
LDMC_mg/g & Leaf dry-matter content & $\mathrm{FCI}$ \\
Chlorophyll_FCI & Chlorophyll content per leaf area & $\mathrm{N} / \mathrm{mm}$ \\
LeafTough_N/mm & Leaf toughness & $\mathrm{mm}$ \\
LeafThick_mm & Leaf thickness & $\mathrm{g} / \mathrm{cm}^{3}$ \\
SSD_g/cm 3 & Stem specific density (from branch) & $\%$ \\
PithProp_\% & Proportion of pith cross-sectional area & $\%$ \\
XylProp_\% & Proportion of xylem cross-sectional area & $\%$ \\
BarkProp_\% & Proportion of bark cross-sectional area & $\%$ \\
VesselDens_n/mm 2 & Vessel density & $\mathrm{n} / \mathrm{mm}^{2}$ \\
VesselDiam_micom & Vessel diameter & $\mu \mathrm{m}$ \\
StomDens_n/mm ${ }^{2}$ & Stomata density & $\mathrm{n} / \mathrm{mm}^{2}$ \\
StomLength_micom & Stomata length & $\mu \mathrm{m}$ \\
Hpot95_m & Potential plant height (95\% percentile) & $\mathrm{m}$ \\
DS_anemo-0_zoo-1 & Dispersal syndrome & $0-\mathrm{Anemochory} ; 1-$ Zoochory \\
SeedMass_g & Seed mass & $\mathrm{g}$ \\
Kpot_kg/m/s/Mpa & Potential hydraulic conductance & $\mathrm{kg} / \mathrm{m} / \mathrm{s} /$ Mpa \\
\hline
\end{tabular}

Table 3. Description of column names of the Seed mass spreadsheet from the seed_mass.xlsx file.

\begin{tabular}{ll}
\hline \multicolumn{1}{c}{ Column Names } & Description \\
\hline Species & Scientific name \\
\hline Number of evaluated seeds & $\begin{array}{l}\text { Number of seeds used to obtain the mean mass value or referred } \\
\text { in the literature }\end{array}$ \\
\hline Total dry seed mass $(\mathrm{g})$ & Total seed dry mass measured or referred in the literature \\
\hline Mean dry mass per seed $(\mathrm{g})$ & Seed dry mass mean value \\
\hline Herbarium code & $\begin{array}{l}\text { Code of the specimen in the herbarium Dr. Roberto Miguel Klein } \\
\text { (FURB); for seed dry mass obtained from our samples, the } \\
\text { number of the sample is provided }\end{array}$ \\
\hline Reference & Short reference (the full reference is in the Reference spreadsheet) \\
\hline
\end{tabular}




\section{Methods}

We chose the functional traits that are presented here following three principles: the traits must represent key aspects related to performance traits; they should be easy to measure using our laboratory equipment; the measuring cost should be small in relation to our logistical capacity to collect individual samples to represent functional traits on a regional scale. Our procedures of trait measuring were based on the protocol developed by [18] and on the methods that are provided by [10], with adaptations to fit our aims. Hence, we measured several traits from each individual sample and combined them with data gathered by the Forest and Floristic Inventory of Santa Catarina (hereafter IFFSC; www.iff.sc.gov.br) and from the literature.

\subsection{Study Area and the Species Selection}

Our aim was to build a representative functional trait dataset of the species pool of the Itajaí-Açu watershed (with an area of $15,335 \mathrm{~km}^{2}$, located between the latitudes $26^{\circ} 24^{\prime} 31^{\prime \prime} \mathrm{S}$ and $27^{\circ} 52^{\prime} 29^{\prime \prime} \mathrm{S}$, and the longitudes $48^{\circ} 34^{\prime} 16^{\prime \prime} \mathrm{W}$ and $50^{\circ} 21^{\prime} 05^{\prime \prime} \mathrm{W}$ ) in the state of Santa Catarina, Southern Brazil. The Itajaí-Açu watershed is covered mostly $(\sim 78 \%)$ by the subtropical Atlantic Rain Forest [19]. We designed the survey plan based on the most common species occurring in the watershed. For this, we selected the species using data from the first measurement cycle (conducted between 2007 and 2011) of the systematic field survey carried out by the IFFSC. The IFFSC implemented 4400.4 ha sample units (SU) all over the state of Santa Catarina, wherein all individuals with diameter at breast height $\geq 10 \mathrm{~cm}$ were identified and measured (more details in [20]). We selected 64 SU within the Itajaí-Açu watershed that were covered by the subtropical Atlantic Rain Forest. Based on the data collected within these SU, we selected the species that presented more than 30 individuals per hectare in at least one SU.

Following this criterion, we listed in 2017 the 102 most common species in the study area. However, our dataset contains 117 species, with individual samples ranging from one to six individuals per species. The number of sampled species was greater than the number of listed species in 2017 because the IFFSC floristic data were updated during its second remeasurement cycle (between 2016 and 2017), which was being conducted during our sampling period. For this reason, from the 117 species that are presented in the dataset, 89 species were in the 2017 list. The additional species may not be regarded as the most common species in the study area; although, they were sampled following a list made in 2016 and were maintained in the dataset. The dataset includes trees, tree ferns, palms, and an exotic species (Hovenia dulcis).

\subsection{Trait Measurements at Individual Level}

We conducted field surveys in sites where we previously knew that the listed species occurred. We sought to sample at least five individuals per species; however, we sampled one to six individuals by each species. The individual samples consisted of branches with leaves with $\sim 50 \mathrm{~cm}$ length, which were collected preferably from an adult individual. When adults were absent or inaccessible, we collected samples from juveniles. The trimmer length also restricted the sample collection, which was between 4 and $6 \mathrm{~m}$. In the field, we stored the samples inside plastic bags. In the laboratory, we rehydrated the samples for at least $12 \mathrm{~h}$ in a bucket of water covered with a black bag. Afterwards, we measured morphological and anatomical features of branches and leaves of each specimen, as summarized in Figure 3 and described in the subsequent sections.

\subsubsection{Leaf Measurements}

From each sample, we selected six leaves; we used one of them to measure stomata traits and the other five to measure mass, area, thickness, toughness, and chlorophyll content. For compound leaves, we considered the leaflet as a leaf unit.

To measure stomata traits, we cleaned the leaf to remove hairs and dirt. We painted the leaf with clear nail polish on its two sides (adaxial and abaxial). After it dried, we removed the polish and 
placed it in a microscope slide. We took microscopy images using a Zeiss AxioCam ICc 3 camera and the Zen Blue 2.3 software [21]. We searched for stomata on both sides of the leaf; however, only three individuals presented stomata on the adaxial side. We took five images from different positions of both sides of the leaf. Through these images, we measured the stomata density and stomata length using the Zen Blue 2.3 software [21]. Stomata density is the number of stomata per area unit. Stomata length is the guard cell length in three stomata of each image. We reported individual mean stomata density and length only for the abaxial side.

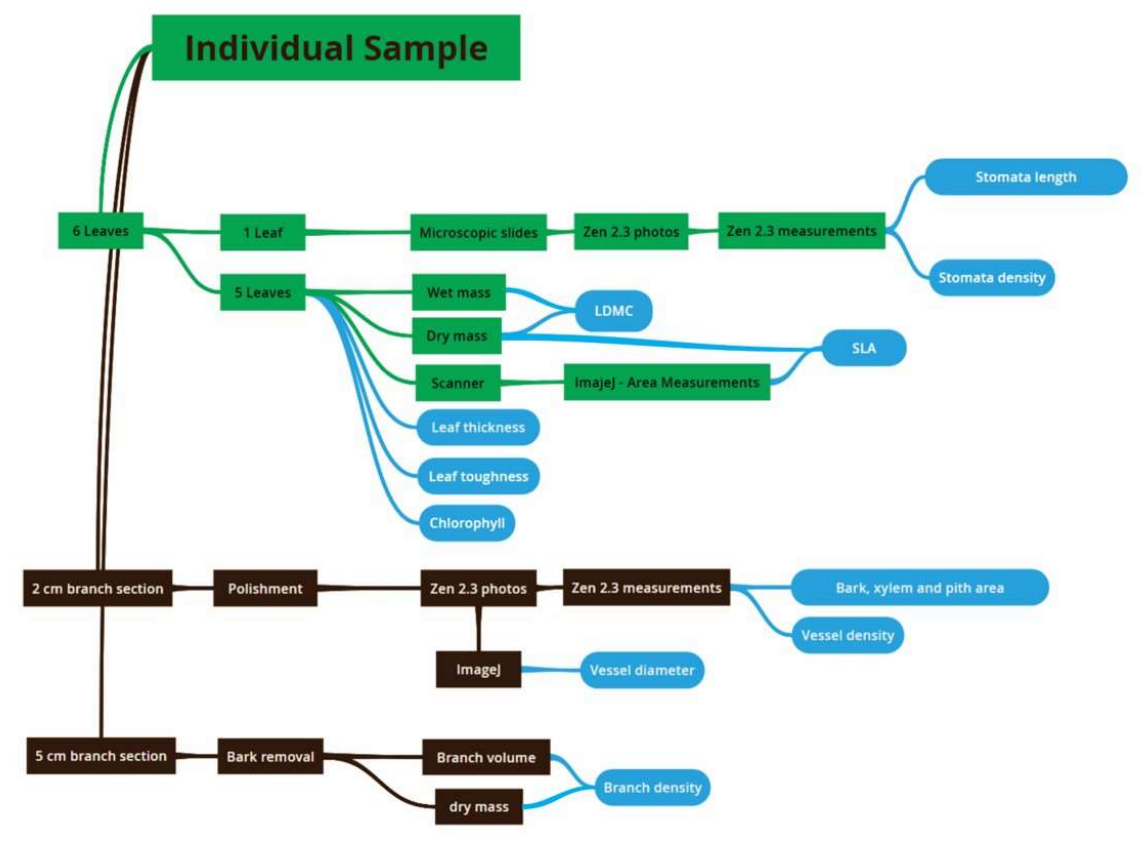

Figure 3. Schematic view of the process employed to obtain individual traits measurements. Green boxes refer to procedures related to leaf traits; brown boxes refer to procedures related to wood traits; blue boxes represent the obtained functional traits. LDMC_Leaf Dry Matter Content; SLA-Specific Leaf Area.

We used the five leaves to measure: (1) chlorophyll content using the Clorofilog-FALKER (Falker Chlorophyll Index-FCI); (2) leaf thickness using a digital pachymeter; (3) leaf wet and dry mass; the leaves were dried at $60^{\circ} \mathrm{C}$ for $48 \mathrm{~h}$; (4) leaf area was measured using scanner images and the ImageJ $1.49 \mathrm{~V}$ software [22]. All these leaf traits are reported as means of individual measurements; (5) one of these five leaves was used to measure leaf toughness through a punch artefact [18].

\subsubsection{Branch Measurements}

We collected two sections from the base of a branch of woody species, and from the middle of the main rachis of compound leaves of non-woody species (tree ferns and palms). The first section had about $2 \mathrm{~cm}$ length and was used to obtain images of wood. We polished it with sandpaper to adjust its shape; afterwards, we sliced it with a bistoury in order to enhance the visualization of wood vessels. We captured images in panoramic view and in $5 \mathrm{x}$ zoom with a stereoscopic microscope using the Zeiss AxioCam ICc 3 and the Zen Blue 2.3 software [21].

We took panoramic images to measure bark, xylem, and pith cross-sectional areas. For woody species, we estimated these areas based on diameter; we took the measures in two orthogonal directions and then calculated the mean diameter (Figure 4) using the Zen Blue 2.3 software [21]. We employed a different procedure to estimate bark, xylem, and pith areas of non-woody species due to differences in anatomical tissues. For such plants, we considered the bark as the peripheral sclerenchyma (for tree ferns) or the peripheral region with denser vascular bundles (for palms). In turn, we defined the xylem 
area as the vascular bundle area (outside bark in palms) and the pith area as the full parenchyma area (Figure 5). Instead of diameters, we measured the area of polygons to calculate bark, xylem, and pith areas of tree ferns and palms.

We used the zoomed images to measure vessel density and diameter. We quantified vessel density through manual counting of vessels in a selected area of the image. We considered just the area of the image where vessels could be clearly distinguished from wood tissues. This procedure was carried out using the Zen Blue 2.3 software [21]. We determined vessel area using a semi-automated procedure in the Image $1.49 \mathrm{v}$ software [22]. We calculated vessel diameter based on the vessel area of each counted vessel, assuming that the vessels were circular. The vessel mean diameter $\left(D_{h}\right)$ for each individual sample was calculated as the average hydraulic weighted vessel diameter:

$$
D_{h}=\left[(1 / n) \sum_{i=1}^{n} d_{i}^{4}\right]^{1 / 4}
$$

where $d_{i}$ is the diameter of the $i$ th vessel $\left(d_{i}=1,2, \ldots, n\right)$.

From the second branch section, which had about $5 \mathrm{~cm}$ length, we measured its wet volume and dry mass. We removed the bark of the branch section and measured its volume as the mass of displaced water. We obtained its dry mass after drying it at $60^{\circ}$ for $48 \mathrm{~h}$.

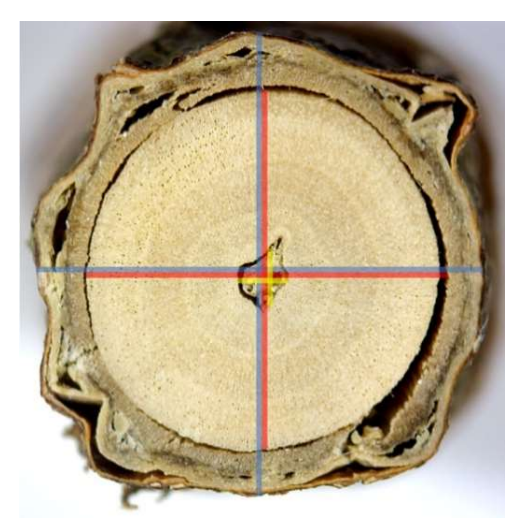

Figure 4. We estimated bark, xylem, and pith areas through mean diameters obtained from two orthogonal measures. First, we measured the whole branch diameter (blue), xylem + pith diameter (red), and pith diameter (yellow) in two orthogonal directions. We obtained the bark area by discounting the xylem + pith area from the whole branch area. Xylem area was obtained by discounting the pith area from the xylem + pith area (Adapted from [18]).

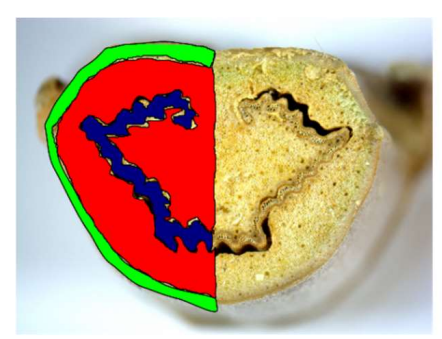

(a)

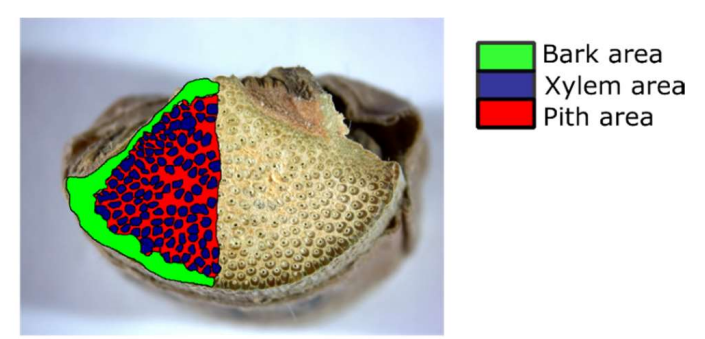

(b)

Figure 5. Schematic view of the procedure employed to measure bark, xylem, and pith areas of non-woody species. (a) Tree fern Dicksonia sellowiana; (b) palm Syagrus romanzoffiana. Only half of the image was painted for a better visualization of the area considered in the different tissues. 


\subsection{Trait Measurements at Species-Level}

We report four traits that were measured only at species level, namely, seed mass, dispersal syndrome, potential plant height, and potential hydraulic conductivity. (1) Seed mass consists of the average seed dry mass obtained from direct measurements; when seed samples were not available, we searched for seed dry mass values in the literature. We presented all seed mass measurements, literature values, and references in the file seed_data.xlsx. We measured seed mass from specimens deposited at the Dr. Roberto Miguel Klein herbarium (FURB) [23]. We dried the seeds at $60{ }^{\circ} \mathrm{C}$ for $48 \mathrm{~h}$ before being weighed. Spore mass of tree fern species was estimated from spore radius; we assumed that the spores were spherical and had a density of $0.5 \mathrm{mg} \mathrm{mm}^{-3}$; (2) Dispersal syndrome and (3) potential plant height were obtained from the IFFSC database. We calculated the potential plant height as the $95 \%$ percentile of the maximum plant height of the species recorded in all of the IFFSC sample units.

We estimated the (4) potential hydraulic conductivity (Kpot) through the Hagen-Poiseuille law [24]:

$$
K p o t=\left(\frac{\pi \rho}{128 \eta}\right) \times V D \times D_{h}^{4}
$$

where $\rho$ is the water density at $20^{\circ} \mathrm{C}\left(998.2 \mathrm{~kg} \mathrm{~m}^{-3}\right), \eta$ is the water viscosity at $20^{\circ} \mathrm{C}\left(1.002 \times 10^{-3} \mathrm{~Pa} \mathrm{~s}\right)$, $V D$ is the vessel density, and $D_{h}$ is calculated through the Equation (1), in meters.

\section{Conclusions}

Our dataset provides high quality information about functional traits of plant species that may be useful for researchers at both regional and global scales. On regional scales, the procedures described here may support researches who intend to increase the number of sampled species and individuals, as well as the geographical range of our dataset. In addition, it may add to studies about the Atlantic Forest, given that many species in our dataset occur in the southern and southeastern Atlantic Forest. On a global scale, one may use the dataset to incorporate trait information of species occurring in the Atlantic Forest, the plant species richest domain in Brazil.

We also proposed a method to interpret functional traits of distinct anatomical groups, such as branches of woody and non-woody species. In the Atlantic Forest, non-woody species usually present a great proportion of the individuals in a community; therefore, they should be considered in the analysis of functional diversity and community composition. Finally, the images may be useful to assess other anatomical traits that were not covered in the data tables, for species anatomical determination and/or to build educational charts or other related materials.

Author Contributions: A.V.R. and A.L.G. designed and conducted the work. A.V.R. and F.L.V.B. conducted the individual trait measurements. A.S. was responsible by the stomata images and their measurements. A.C.V. and L.Z.O. made significant improvements in the text. A.V.R., F.L.V.B. and L.Z.O. revised the dataset. A.V.R. led the writing of the manuscript.

Acknowledgments: A.V.R. is grateful for the MSc grant provided by the Coordenação de Aperfeiçoamento Pessoal do Ensino Superior (CAPES), F.L.V.B. is grateful for the undergraduate grant provided by the Conselho Nacional de Desenvolvimento Científico e Tecnológico $(\mathrm{CNPq})$, A.S. is grateful for the undergraduate grant provided by the State of Santa Catarina. We are also grateful to Luis Adriano Funez, Fábio Fiamoncini Pastório and Anderson Kassner Filho for helping in the field data collection campaigns and in the identification of plant species.

Conflicts of Interest: The authors declare no conflict of interest.

\section{References}

1. Diaz, S.; Cabido, M.; Casanoves, F. Plant functional traits and environmental filters at a regional scale. J. Veg. Sci. 1998, 9, 113-122. [CrossRef]

2. Westoby, M.; Wright, I.J. Land-plant ecology on the basis of functional traits. Trends Ecol. Evol. 2006, 21, 261-268. [CrossRef] [PubMed] 
3. Poorter, L.; McDonald, I.; Alarcón, A.; Fichtler, E.; Licona, J.C.; Peña-Claros, M.; Sterck, F.; Villegas, Z.; Sass-Klaassen, U. The importance of wood traits and hydraulic conductance for the performance and life history strategies of 42 rainforest tree species. New Phytol. 2010, 185, 481-492. [CrossRef] [PubMed]

4. Díaz, S.; Kattge, J.; Cornelissen, J.H.C.; Wright, I.J.; Lavorel, S.; Dray, S.; Reu, B.; Kleyer, M.; Wirth, C.; Prentice, I.C.; et al. The global spectrum of plant form and function. Nature 2016, 529, 1-17. [CrossRef] [PubMed]

5. Violle, C.; Garnier, E.; Lecoeur, J.; Roumet, C.; Podeur, C.; Blanchard, A.; Navas, M.L. Competition, traits and resource depletion in plant communities. Oecologia 2009, 160, 747-755. [CrossRef] [PubMed]

6. Götzenberger, L.; de Bello, F.; Bråthen, K.A.; Davison, J.; Dubuis, A.; Guisan, A.; Lepš, J.; Lindborg, R.; Moora, M.; Pärtel, M.; et al. Ecological assembly rules in plant communities-approaches, patterns and prospects. Biol. Rev. 2012, 87, 111-127. [CrossRef] [PubMed]

7. Díaz, S.; Cabido, M. Vive la différence: Plant functional diversity matters to ecosystem processes. Trends Ecol. Evol. 2001, 16, 646-655. [CrossRef]

8. Diaz, S.; Hodgson, J.G.; Thompson, K.; Cabido, M.; Cornelissen, J.H.C.; Jalili, A.; Montserrat-Martí, G.; Grime, J.P.; Zarrinkamar, F.; Asri, Y.; et al. The plant traits that drive ecosystems: Evidence from three continents. J. Veg. Sci. 2004, 15, 295-304. [CrossRef]

9. Violle, C.; Navas, M.L.; Vile, D.; Kazakou, E.; Fortunel, C.; Hummel, I.; Garnier, E. Let the concept of trait be functional! Oikos 2007, 116, 882-892. [CrossRef]

10. Pérez-Harguindeguy, N.; Díaz, S.; Garnier, E.; Lavorel, S.; Poorter, H.; Jaureguiberry, P.; Bret-Harte, M.S.; Cornwell, W.K.; Craine, J.M.; Gurvich, D.E.; et al. New handbook for standardised measurement of plant functional traits worldwide. Aust. J. Bot. 2013, 61, 167. [CrossRef]

11. Westoby, M.; Falster, D.S.; Moles, A.T.; Vesk, P.A.; Wright, I.J. Plant Ecological Strategies: Some Leading Dimensions of Variation between Species. Annu. Rev. Ecol. Syst. 2002, 33, 125-159. [CrossRef]

12. Carlucci, M.B.; Streit, H.; Duarte, L.D.S.; Pillar, V.D. Individual-based trait analyses reveal assembly patterns in tree sapling communities. J. Veg. Sci. 2012, 23, 176-186. [CrossRef]

13. Van der Sande, M.T.; Poorter, L.; Kooistra, L.; Balvanera, P.; Thonicke, K.; Thompson, J.; Arets, E.J.M.M.; Garcia Alaniz, N.; Jones, L.; Mora, F.; et al. Biodiversity in species, traits, and structure determines carbon stocks and uptake in tropical forests. Biotropica 2017, 49, 593-603. [CrossRef]

14. Kröber, W.; Li, Y.; Härdtle, W.; Ma, K.; Schmid, B.; Schmidt, K.; Scholten, T.; Seidler, G.; von Oheimb, G.; Welk, E.; et al. Early subtropical forest growth is driven by community mean trait values and functional diversity rather than the abiotic environment. Ecol. Evol. 2015, 5, 3541-3556. [CrossRef] [PubMed]

15. Díaz, S.; Lavorel, S.; Chapin, F.S., III; Tecco, P.A.; Gurvich, D.E.; Grigulis, K. Functional diversity-At the crossroads between ecosystem functioning and environmental filters. In Terrestrial Ecosystems in a Changing World; Springer: Berlin, Germany, 2007.

16. Kattge, J.; Díaz, S.; Lavorel, S.; Prentice, I.C.; Leadley, P.; Bönisch, G.; Garnier, E.; Westoby, M.; Reich, P.B.; Wright, I.J.; et al. TRY-A global database of plant traits. Glob. Chang. Biol. 2011, 17, 2905-2935. [CrossRef]

17. Paine, C.E.T.; Baraloto, C.; Díaz, S. Optimal strategies for sampling functional traits in species-rich forests. Funct. Ecol. 2015, 29, 1325-1331. [CrossRef]

18. Costa, F.; Schietti, J.; Emilio, T.; Poorter, L. Protocol for Screening Functional Traits of the Tree Community Using Understory Material. PPBio—Programa Pesqui. em Biodiversidade. Ministério da Ciência, Tecnol. e Inovação; 2015; pp. 1-6. Available online: https://ppbio.inpa.gov.br/sites/default/files/protocol_ functional_traits.pdf (accessed on 10 April 2018).

19. Oliveira-Filho, A.T. Um Sistema de Classificação Fisionômico-Ecológico da Vegetação Neotropical: segunda aproximação. In Fitossociologia No Brasil; UFV: Viçosa, Brazil, 2015; Volume 2, pp. 452-474.

20. Vibrans, A.C.; Sevgnani, L.; Lingner, D.V.; De Gasper, A.L.; Sabbagh, S. Inventário florístico florestal de Santa Catarina (IFFSC): Aspectos metodológicos e operacionais. Pesqui. Florest. Bras. 2010, 30, 291-302. [CrossRef]

21. Carl Zeiss Microscopy GmbH. Zen Blue. Available online: https://www.zeiss.com/microscopy/int/ products / microscope-software/zen-lite.html (accessed on 7 May 2018).

22. Schneider, C.A.; Rasband, W.S.; Eliceiri, K.W. NIH Image to ImageJ: 25 years of Image Analysis. Nat. Methods 2012, 9, 671-675. [CrossRef] [PubMed] 
23. De Gasper, A.; Christian Vibrans, A.; Funez, L.A.; Rigon, M.J., Jr.; Bittencourt, F.; Vieira, C., Dr. Roberto Miguel Klein Herbarium (FURB), Blumenau, Southern Brazil. PhytoKeys 2014, 42, 21-37. [CrossRef] [PubMed]

24. Tyree, M.T.; Ewers, F.W. The Hydraulic Architecture of Trees and Other Woody Plants. New Phytol. 1991, 119, 345-360. [CrossRef] 